\title{
God help us: Spirituality and religiosity amid corona pandemic in Pakistan
}

\author{
Kausar Ali | Huang Minxing* \\ Institute of Middle Eastern Studies, Northwest University, Xian, Shaanxi, China. \\ *Corresponding Author Email: 2234794148@qq.com
}

\begin{abstract}
This research discusses the response of the religious people to the corona pandemic in Pakistan. The study aims to answer why the Islamists refused to cooperate with the state authorities in its struggle against the pandemic? This study is based on the theory of existential security which states that natural calamities and disasters always increase religiosity in the people. This study is based on analysing all the existing primary and secondary sources in the form of books, research articles and government reports. The discussion in this paper is based on the qualitative analysis of all the existing sources. This study has argued that the Islamists refused to support the state policymakers because they firmly believed that the virus emerged because of Allah's wrath. The study has also found that the response of the Tablighi Jamaat (henceforth TJ), other religious organisations, and clerics amid the coronavirus in the country was indeed a religious coping strategy. This strategy is commonly used by people whenever they face a life-threatening situation. The study suggests that Pakistan could not resist the Islamists because resisting them could cause severe problems in the country.
\end{abstract}

Article History:

Received:

June 16, 2021

Revised:

July 10, 2021

Re-revised:

August 7, 2021

Accepted:

August 17, 2021

Published:

September 15, 2021

Keywords: COVID-19, Ijtima, Religious organizations, Tablighi Jamaat, Political Islam, Religious trends, Practicing religious duties, Insecurity, Religiosity.

\section{How to Cite:}

Ali, K., \& Minxing, H. (2021). God help us: Spirituality and religiosity amid corona pandemic in Pakistan. Liberal Arts and Social Sciences International Journal (LASSIJ), 5(2), 43-60. https://doi.org/10.47264/idea.lassij/5.2.4

\section{Publisher's Note:}

IDEA PUBLISHERS (IDEA Journals Group) stands neutral with regard to the jurisdictional claims in the published maps and the institutional affiliations.

\section{Copyright:}

(C) 2021 The Author(s), published by IDEA PUBLISHERS (IDEA Journals Group).

\section{Licensing:}

This is an Open Access article published under the Creative Commons Attribution-NonCommercial 4.0 International License (http://creativecommons.org/licenses/by-nc/4.0/) 


\section{Introduction}

The first case of the COVID-19 was reported to have come from a seafood market in the Chinese city of Wuhan. The deadly infection spread very rapidly not only throughout China, but all over the world (Jan et al., 2020; Zi-Zu et al., 2020). In January of 2020, the World Health Organization (WHO) declared the disease a "Public Health Emergency of International Concern" (PHEIC) (World Health Organization, 2020). This declaration of the international body alarmed state managers in every country. According to Frei-Landau, "following the efforts to control the spread of the 2019 novel coronavirus (COVID-19) pandemic, many countries around the world adopted a quarantine policy, which resulted in people's forced isolation" (Frei-Landau, 2020, p. 258).

Pirutinsky has argued that religion has always been an essential part of people's daily social lives (Pirutinsky et al., 2020). This is true even today, where the role of religion has only increased in the modern world. Bentzen (2020) argued that there was a time when some philosophers believed that religion would lose its importance in modern society - however, this idea proved to be wrong. Today, more than $83 \%$ of people believe in God (Bentzen, 2020). The importance of religion and religious organizations in the fight against the coronavirus is more clearly seen in a report issued by WHO in April 2020. It was reported that religious and other faith-based societies could play a significant role in saving lives by being a source of support, guidance, and by providing spiritual healings. In their report, the WHO instructed state managers in every country to keep in touch with religious and faith-based organizations (Shaheen et al., 2020; World Health Organization, 2020).

This pandemic constituted a severe challenge to religious and faith-based communities throughout the entire world (Sulkowski \& Ignatowski, 2020). One study found that religiosity and spirituality have always played a significant role amid the days of such disasters because it provides mental peace and security in fighting against illness and stress. Erica Evans (2020) argued that religious people could either be part of the problem, or part of the solution (Evans, 2020). Hashmi (2020) argued that some faith-based organizations in developing countries avoided the recommended precautions, citing that 'Allah is with them' and that 'He is an excellent guardian' (Hashmi et al., 2020).

This research article discusses the response of the religious people to the current fatal diseaseinflicting virus known as the coronavirus, otherwise known as Covid-19, in Pakistan. Throughout the current crisis, several religious groups around the world accepted the threat created by the pandemic; thus, supported the state and its machinery in controlling the spread of the pandemic. However, in some other countries, the religious groups not only rejected the crisis but also continued with their huge gatherings, creating a dangerous situation for the people involved by acting as a possible site where covid could spread to large numbers of people. Pakistan was one of those Muslim countries where religious people not only refused to keep with social distancing guidelines, but also tried to explain the pandemic in religious terms, rather than agree with the general scientific community. In order to cope with the challenge of the pandemic, the people of Pakistan used religion and morality. They concluded that the pandemic was spreading solely because Allah the almighty was not happy with them. This research paper aims to understand the question under discussion in the light of a theory called the 'existential insecurity theory'. This theory suggests that natural calamities increase religiosity in people because people consider such challenges as the test of God. In order to overcome the problems created by the challenges, people turn to God for help and guidance. 


\section{Literature review}

In some countries, religious organizations supported political leadership and their actions to curb the pandemic's effects. However, it did not work in Pakistan for a multitude of reasons. In order to contain the virus, religious gatherings were banned in some Muslim countries such as Saudi Arabia, Turkey, Egypt, Jordan, and Malaysia; it was in these countries that Fatawa's religious decrees were issued in. Makkah and Madinah, two of the holiest places in the entire world for Muslims, were also closed for public worship. Nevertheless, the religious people and clerics of Pakistan refused to accept state orders and continued their large gatherings (Sattar, 2020). According to Noreen (2020), "The Pakistani government has yet to decide about the imposition of a ban on mosque prayers and large religious gatherings, due to fear of a backlash from Islamist groups. Prominent religious clerics need to be taken in confidence to pursue people intellectually about the health measures and precautions" (Noreen et al., 2020, p. 5). Islam as a religion believes in social distancing regulations, particularly when people struggle against a life-threatening disease. Prophet Muhammad (PBUH) once remarked, "If you hear of an outbreak of plague in a land, do not enter it; and if the plague breaks out in a place while you are in it, do not leave that place" (Yulianto, 2020).

Quadri (2020) has also argued that Religious Congregations (RC) amid the current pandemic could be very challenging for the state policymakers in the developing countries. He writes that the annual gatherings of the TJ in Malaysia, Pakistan, and India became a source of spreading the pandemic, or what he called "COVID-19 hotspots" (Quadri, 2020. p. 2219). Badshah and Ullah (2020) have also argued that those missionaries who attended the Raiwind Tablighi Ijtima moved towards different cities of the country. These missionaries urge local people to come to the mosque, and where one of the senior preachers delivers a comprehensive religious speech called the bayan in the TJ context (Badshah \& Ullah, 2020). The Indian media, supported by the right-wing circles of the country, also blamed the Nizamuddin Markaz of the TJ. They started labeling the Tablighis as the "corona-Jihadis" (Agha, 2020).

The TJ of Pakistan held its two annual gatherings called the Ijtima at Raiwind, located near Lahore. The first large congregation was organized in mid-March, and the second meeting was held in early November. According to several sources, 70,000 to 80,000 people attended the mid-March Ijtima. According to TJ, more than 250,000 people from Pakistan and other foreign countries participated in the March Ijtima (Chaudhery, 2020). The second annual congregation of TJ was held in the November of 2020. It was reported that more than 50,000 Islamists participated in the November gathering. This annual meeting was held at a time when the second wave of coronavirus had already started in the country (Dawn, 2020). Both the March and November gatherings were held, which was still when the country was facing the threat of COVID-19. The only difference between the two gatherings was that in the first case, the state requested the $\mathrm{TJ}$ to postpone its gathering, while in the second case, it was allowed by the state, although under "strict restrictions." According to Ahmad (2020), "those who had attended the March congregation had spread the virus around the world from Kyrgyzstan to Gaza" (Ahmad, 2020, p. 257). Ahmad further argued that Maulana Taqi Usmani, a leading Islamic scholar of Pakistan said that cure of the pandemic was revealed to a TJ member by the Messenger of Allah in his dream. Ahmad (2020) argues that it is because of the distrust between the Islamists and the state authorities that caused the religious people to turn down state's social distancing instructions. Its origin, he argues, can be found in the colonial period (Ahmad, 2020).

The literature mentioned above elucidates that different types of challenges in human society 
throughout history have always increase religious feelings. During the current pandemic, different religious and faith-based organizations turned to God or a supernatural force, hoping that He will keep them safe from its harmful effects. When it comes to the TJ, it held two important annual meetings in Pakistan amid the pandemic. The leaders of other religious organizations and prayer-leaders also continued their gatherings in the country. Some of the sources mentioned above stated that religious gatherings became a source of spreading the virus in the country. These sources did not answer why the religious people and TJ refused to cooperate with the state. Ahmad's article, titled "The Politics of Congregational Prayer: Trust, Public Health, and Religious Authority in Pakistan" argues that it is due to the mistrust and lack of understanding between the religious people and the state. The former does not trust the later. Partly correct, this study argues that the religious people of Pakistan trusted Allah more than any institution of the state. The paper argues that the Islamists declared the pandemic as an act of Allah, and they turned to Him because they firmly believed that He is the most powerful and magnificent. Moreover, the writers of other studies did not apply any social theory on the response of religious people and other faith-based organizations. This paper aims to apply the existential security theory and analyse the content accordingly.

This research article aims to answer why the TJ and other clerics continued their religious gatherings, despite the growing number of cases in the country. The study is based on the existential security theory, which states that all types of insecurity increase religiosity. First, we discuss the existential security theory and then come to the response of the TJ and other clerics to the COVID-19 pandemic in Pakistan. This article argues that the people of Pakistan believed that the pandemic was a punishment of Allah and could be defeated only with the help of religion. This research article has its own significance because it discusses the response of the Islamists to the current pandemic in Pakistan. Thus, this article contributes to the international debate on the role of religious and faith-based organizations amid the COVID-19 pandemic. This article has argued that the state managers could not force the religious people to close down places of worship. It is suggested that the state managers feared that forcing the religious groups and people could be more dangerous than the ongoing pandemic in the country. That is why the policy of appeasement was followed once again.

\section{Theoretical framework}

Why are some people more religious when we compare them with others living in another society? This question was answered by Norris and Inglehart (2011) by putting forward a theory called the 'existential security theory'. This theory argued that insecurities are directly related to people's religiosity. They have argued that people who face an insecure situation will be more religious. Every religion gives hope to people in times of crisis and insecurity, which is also why people participate in religious ceremonies ( Norris \& Inglehart, 2011). The theory of existential security is related to a particular condition in which people face a life-threatening situation. Both the authors have argued that the September 11 attacks on the United States of America in 2001 turned people's attention towards religiosity because they felt insecurity after the devastating attack (Immerzeel \& Tubergen, 2020).

According to many social scientists, one of the fundamental functions of religion is to help people cope with existing issues and the challenges they face in society. They argued that these challenges might be in the form of war, natural calamities, illness, or any other social and material deprivation (Hollinger \& Muckenhuber, 2019). In such a terrible condition, people often use religious coping strategies. As Pargament et al. (1990) argued, "Coping is generally 
viewed as a process through which individuals try to understand and deal with significant personal or situational demands in their lives" (Pargament et al., 1990, p. 795). It has been found in various research studies that religion plays a significant factor in the lives of many people (Ano \&Vasconcelles, 2005). In a particularly life-threatening situation, why do people turn to God? The answer lies in the fact that people think that God is angry with them. And as a result, they face grave problems and tragedies in their lives.

Chen (2008) has argued that the 1998 Indonesian economic crisis increased religiosity in the people, with most of the affected families responding through religiosity, such as by reciting the Holy Qur'an. Chen (2008) argued that they also started sending their children to religious schools called madrassas. According to Chen, religion gave them moral and psychological support (Chen, 2008). Clark and Lelkes (2005) argued that religious people are found relatively satisfied during natural disasters. Why does this happen? The answer is that religious institutions give them strong support in the form of friendship and social networks (Clark Lelkes, 2005). Krause (2009) has argued that religious people think that Allah Almighty is with them and that He will get them out of this challenging situation (Krause, 2009).

The findings of the existential security theory suggest that problems are linked to God and that people become more religious throughout their lives - the present study is based on this theory. It discusses the response of the TJ and other clergies aimed at the corona pandemic in Pakistan. An overwhelming majority of the people in Pakistan firmly believed that the corona pandemic was a test of Allah and that only God could save them from COVID-19. When the coronavirus pandemic caused havoc in Pakistan, the religious communities and faith-based organizations called it an act of God (Allah ka az'ab hai) and rejected state instructions of social distancing. A well-known Islamic scholar, Mufti Taqi Usmani, supported state policies in containing the virus. He also requested the people of Pakistan to pray to Almighty Allah (Mahmood, 2020). The Prime Minister of Pakistan also requested the people to worship Allah for the eradication of the COVID-19. It was reported that Yaum-i-Tauba (the day of forgiveness) and Yaum-iRahmat (the day of blessing) would be observed across the country (Raza, 2020). It is suggested that both the religious circles and the state's political leadership also turned to God, hoping that He will eliminate the fatal disease-inflicting virus.

\section{Research methodology}

In order to investigate and answer the question asked above, this study employs descriptive and analytical methods. The researcher has used all the available data and sources in the form of research papers, books, magazines articles, and articles published in national and international newspapers and other publications. The researcher also utilized a variety of other sources of information, such as electronic and social media networks. Firstly, we collected all these materials before analysing and vetting each source very carefully. In order to answer the question asked at the beginning of this study, both descriptive and analytical methods have been used and applied in the discussion of this study. The importance of this study lies in the fact that it aims to contribute to the ongoing research and discussion on the role of religion and religious movements amid the current challenge of the COVID-19 pandemic. There are some limitations while dealing with the research question. The fieldwork and participant observation methods were the best ways to explore the issue, but it was not possible due to the strict rules of lock-down in the country. The researcher could not visit some specific areas for the collection of materials/data for this study. 
This paper has been divided into four main parts. The first part of the paper deals with the introduction and the literature on the topic under discussion. It will help readers understand the background and the work done by others. This part also describes the brief importance of this research. The readers will understand the question of this study as well. The second part of the paper explains the theory that has been applied to the paper. The third part of the paper put light on the proper order of the study. The final and last part is the main body of the research paper. This part deals with the role of the Tablighi Jamaat and other clergies of Pakistan during the days of the current pandemic. The study suggests that the current disease increased religiosity in the country due to the majority of people in Pakistan strongly believing that the coronavirus was the punishment of Allah. As is discussed in this paper, it is implied that they believed that the pandemic could be defeated by becoming good and practical Muslims.

\section{Discussion and findings}

\subsection{The Tablighi congregation of March and November 2020}

The TJ is a popular proselytizing movement in the entire world. The TJ movement was established in colonial India in the 1920s. This movement was founded by Maulana Mohammad Ilyas (d. 1944). The Maulana had studied in the famous Deoband madrassa, founded after the failure of the 1857 war. This religious movement aimed to save Indian Muslims from anti-Muslim organizations such as Shuddhi and Sangathan, founded by some extremist Hindus during the British rule over India. It is said that extremist Hindus founded these anti-Muslim organizations to re-convert the Mewati Muslims into Hinduism. In order to save the Mewati Muslims from such societies, Maulana Mohammad Ilyas founded the TJ in 1926-27 in the Mewat region of undivided India. Founded in colonial India; the TJ became very popular throughout the world in the 1970s (Nadwi, 1979). Today, Tablighi members and supporters are very active in more than 150 countries. The TJ is also active and popular in Pakistan. The Raiwind markaz (center) of the TJ is one of the most well-known centers of the Jamaat, where thousands of Islamists hold an annual meeting of the TJ called Ijtima each year.

The annual meeting of the TJ has always been a significant public gathering since the very formation of $\mathrm{TJ}$ in colonial India. It is the second-largest Muslim gathering after Hajj (pilgrimage) (Siddiqi, 2010). The March Ijtima of TJ was an annual meeting of only old preachers. They have already spent at least four months in the way of Allah and His beloved Prophet Muhammad (PBUH) (Sahu, 2020). Preachers from India, Afghanistan, China, Palestine, and Indonesia also visited Pakistan to participate in the Ijtima. The November 2020 Ijtima was also held at Raiwind, Lahore, but no other foreigners participated due to the fear of coronavirus (Butt, 2020). In Pakistan, the first case of the COVID-19 was reported in February of 2020. Nevertheless, it was followed by a series of new cases in March of 2020 (Jawed, 2020). Figure 1 shows the coronavirus cases from their origin in Pakistan up to the end of 2020. It also shows that thousands of people in Pakistan died due to coronavirus infections from February to December of 2020. The state report also shows that 10,176 people died of coronavirus in Pakistan (Government of Pakistan, 2020).

Table-1 shows that the number of reported cases and deaths was on the rise in Pakistan. Thus, the pandemic threatened millions of lives in Pakistan. In order to cope with this natural disaster caused by the pandemic, both the TJ and Mullahs responded in the form of religiosity. The TJ held its two annual meetings. One was organized in mid-March, while the second was held in November. The clerics also refused to close down religious places for worship. As the theory 
suggests, people turn to God whenever they cope with a life-threatening situation. Thus, this study also suggests that both the TJ and clerics turned to Allah because they believed that the pandemic was spreading due to sins committed by the followers of Islam throughout the world.

Table-1: This shows the total cases of coronavirus in Pakistan from February to December 2020

\begin{tabular}{|l|c|}
\hline Pakistan & Total cases of coronavirus \\
\hline AJK & 8,277 \\
\hline Balochistan & 18,168 \\
\hline Capital Territory & 37,888 \\
\hline Gilgit Baltistan & 4,875 \\
\hline Khyber Pakhtunkhwa & 58,701 \\
\hline Punjab & 138,608 \\
\hline Sindh & 215,679 \\
\hline Total Cases & 482,178 \\
\hline
\end{tabular}

Source: https://covid.gov.pk/stats/pakistan

According to some sources, the current government of Imran Khan allowed the TJ to hold its annual meeting despite the fact that the pandemic was spreading very rapidly in the country (Shahid, 2020). However, this is not the whole story because the Lahore police requested the TJ elders to postpone their annual meeting, but they rejected such instructions. According to Syed Ghazanfar, "Lahore Capital City Police Officer (CCPO), Zulfiqar Hameed held meetings with the top admin officials of the Jamaat to engage them when reports emerged that thousands of its members are attending the annual event" (Chaudhery, 2020). Some observers believed that the annual meeting was called off because of heavy rain, but the state claimed that it was cut short due to the fear of a pandemic. However, it seems that the annual meeting ended soon due to rain in the city only. There seems to be no reality in the official claims that the gathering of Islamists ended because of the requests of the TJ elders to do so.

The religious communities hold a very negative view of science and its findings. Not all, but most of the conservative groups in the world resisted social distancing (Hill et al., 2020). Nazar Rahman, the current leader of the Tablighi Jamaat of Pakistan, said that every condition comes from Allah. Every Muslim should turn to Him for hidaya and Rahmat (guidance and blessing) (Al-Falah official, 2020). Maulana Tariq Jamil, a prominent Tablighi activist in Pakistan, called it "asmani aafat" (natural calamity) and said that Muslims should not worry about COVID-19. (khof ko dil say nikal do). He said whatever happens on earth comes from Allah. The Maulana gave a message to the Muslims of Pakistan that social distancing should be followed. At the same time, he also requested that the Muslims of Pakistan should turn to God for help during this grave crisis (Samaa TV, 2020). As the existential security theory suggested above, whenever people confront issues and challenges in society, they respond to such problems through a religious coping strategy because they consider such issues an act of God. This is why the TJ refused to postpone its annual meeting. The ordinary Muslims led by religious clerics also opposed the state on the issue of social distancing. The Maulana also blamed the women community of the country for the spread of the pandemic. He said that the virus spread because of "women's immodesty" (Inayat, 2020).

However, this was not the first time in Pakistan that the clerics looked for religious factors that, 
according to them, caused the current pandemic in the world. In the year 1967, monsoon rains damaged some of the areas in Karachi. The religious people searched for the "real" reasons responsible for the dangerous rain. The clerics firmly believed that President Ayub Khan's secular policy was the "real" factor responsible for the damage caused by the rain. The people of Pakistan experienced the same religious response when the October 2005 earthquake destroyed the northern areas of Pakistan (Paracha, 2020). During the time of the current pandemic, when a group of TJ was requested by the local people of a village in Mardan district to postpone their preaching tour, they refused and said, "Ye sab dollar ka chakkar hai...drama hai (this is all about the dollar rate...it is staged)" (Ahmad, 2020). This kind of notion can be found in almost all faith-based organizations and parties. For example, the gathering of Shia pilgrims in the city of Mashhad and Qom to celebrate their famous Nowruz festival, which then became a cause of the coronavirus not only in Iran, but it was also the cause of some of the early cases of Pakistan, which were also linked to the Shia pilgrims (Kermani, 2020).

This study suggests that religious people have always looked for reasons whenever they experienced a natural disaster or any other problem in society. The religious leaders of different religions requested their followers to turn to God or any other supernatural deity for comfort and spiritual power to avoid the harmful effects of the coronavirus. This trend can also be found in the TJ and Mullahs of Pakistan. When the state decided to close down places of worship, clerics opposed it by saying that everything comes under the control of God. The March and November Ijtima of the TJ in 2020 elucidates that the preachers wanted to turn to God to eradicate the COVID-19 not only from Pakistan but from the whole world. It also seems that they would have thought that the disease could not infect the missionaries because of their pious and noble work.

\subsection{The recruitment method of the $\mathbf{T J}$}

The recruitment method of the TJ is significant because it will help a lot in developing our understanding of how it attracts and recruit people for the preaching of Islam not only in Pakistan but in almost every country of the world. Since its formation in colonial India, Bayan (speech) of an experienced preacher plays a significant role in recruiting people for the TJ. The speech revolves around Cheh bata'in (six principles) of TJ supported by verses from the Holy Qur'an and sayings (hadith) of the Holy Prophet (PBUH). The speaker explains the existing conditions of the ummah (Muslim community in the world) and the real causes that led to the downfall of the Muslims in the whole world. The TJ missionaries request ordinary Muslims to spare some time for Allah and His religion. Mamu'n (2019) argued that the people of Mewat, also called Meos, were very poor at the time of the formation of the TJ in colonial India, and many of them lost their properties to Hindu moneylenders. There were severe economic challenges in the 1920s and 1930s in the Mewat region of colonial India. Such socio-economic issues increased religiosity in the people of Mewat (Mamun, 2019). This study suggests that Tablighi preachers would have told the Mewatis that their socio-economic challenges resulted from their irreligiosity and that the solution to their problems lies in becoming good Muslims. The explanation of such existing issues and challenges of the society has always been a key strategy of TJ to recruit people for the propagation of Islam throughout the world.

The holy Qur'an and the hadith books tell us stories of different disasters sent by Allah as a punishment for His creatures. For example, the flood disaster during Prophet Nuh and the disaster of rain of stones during Prophet Lut came as a punishment for the people because they had violated Allah's orders openly. The Muslims believe that all these disasters destroyed old 
nations because they did not believe in their prophets. As a result, God punished them (Suyadi, 2020). A missionary named Maulana Umar Ahmad elucidated that the holy Qur'an is not just a book of history. It is a book of real waqi'yat (events) and Hidayat (guidance) (Being Ummat, 2020). This study suggests that such stories are being used by all Islamic organizations, including the Tablighi Jamaat. The purpose is to recruit ordinary Muslims to work for the cause of Islam in the entire world. Another speech delivered in the TJ Ijtima explains the strategy mentioned above. Maulana Ismail said that the real reason for all the problems and challenges in the current world is that people have forgotten Islam. He assured the participants that Allah Almighty would solve the social, physical, mental, and financial problems of the people if they become good Muslims. He said that peace of mind, happiness, worldly progress and prosperity lies in following the accurate way of Islam only (Sahu, 2020).

Maulana Mohammad Ibrahim Dewla said a very dangerous disease had spread in Madina when the Holy Prophet and his companions came to the city. However, then Allah Almighty eradicated that disease forever. The Maulana asked a question from the participants, asking why Allah the Almighty saved the Muslims from that disease? Then he answered himself by stating that they were very pious and practicing Muslims who worked day and night for the cause of Islam. These are the examples of Allah for all the coming people. Following Allah's orders in one's own life bring changes in the prevailing conditions. (Jab din ayega to halat badal jaingay) (Alami Shura, 2020). This study suggests that Maulana wanted to convey a message to the participants that if they become good Muslims, then God will eliminate this pandemic as He had eliminated the pandemic of Madina.

Another missionary named Maulana Ahmad Laat also delivered a comprehensive lecture. He said that all conditions (halat) come from Allah, and only Allah has the power to change these conditions. He said that people are worried about the current conditions, and everyone is talking about the lock-down, while the cleric requested the people not to worry about the lock-down. Muslims should be worried about their graves only. They should look down at their graves because no one is permanent in this temporary world. What Muslims need is nothing but preparations for the coming death which cannot be avoided. The word "look down" was used several times in the speech (Iqra Media House, 2020). The Maulana used these words for the graves. In the words of Maulana Haji Farooq Bangalore, "Dunya mayoos aor pareshan hai" (The whole world is worried and frustrated) (Being Ummat, 2020). In another Tablighi speech delivered by Hafiz Miraj Uddin said that the present pandemic has spread because of sins committed by the Muslim community only. According to the Maulana, this is the best opportunity to repent before God because He watches everything and everyone in this world. The Maulana also linked people's problems and challenges to their actions. It is a good time for the people to turn to Allah because only Allah can eradicate this pandemic (Tablighi Bayanat Official, 2020).

This study suggests that the Tablighi clerics aimed to convey a message to the participants that Muslims should turn to Allah to keep themselves safe from the adverse effects of the coronavirus. The speeches delivered by the Tablighis show that people should become good Muslims. It seems that the TJ elders aimed to convey messages to the missionaries and other people that they should not be worried about the current conditions. The believers should be worried about their preparations for the coming death only because one cannot avoid it. The decision of the TJ administration to hold its annual meetings amid the days of the coronavirus clearly shows that the Islamists responded to the crisis by adopting what others have named a "religious coping strategy." The TJ could postpose its annual meetings, but its elders did not. 
Here we can see a kind of resemblance between the Tablighi Jamaat and existential security theory. This study suggests that the elders of TJ would have thought that the pandemic was prevailing because of people's sins and that they would not be infected as they were doing a good job. A preacher named Mohammad Amir Rana remarked, "every other year, something or other happens, making people afraid of getting together. We focus on action and deeds, and Allah protects" (Hadid, 2020). It seems that the missionaries would have thought that the pandemic was created because God was not happy with His creatures. In order to make Him happy, the preachers continued their noble work of spreading the religion amid the pandemic.

\subsection{Creating propaganda by the clergies}

The existential security theory states that calamities are always linked to God. The theory also suggests that such calamities increase religiosity in the people. This part of the study aims to focus on the response of clergies in Pakistan. The governments of other Muslim countries banned congregational prayers at the very beginning of COVID-19. In the early days of the disease, most clerics of Pakistan did not cooperate with the state. The Banning of congregational prayer was declared Islamic in other Muslim countries. However, the clergies of Pakistan resisted such restrictions. Some of them declared it "un-Islamic" to ban congregational prayers.

Pakistan, a country having borders with China and Iran, was put on a high alert, given that the coronavirus had already hit both Iran and China. In a country of 220 million people, the state did not have enough resources to curb the virus from further spreading. At the initial stage of the coronavirus in Pakistan, the clergies refused to cooperate. It became a headache for the policymakers to convince them about the threat posed by the COVID-19. In order to convince the clerics, President Arif Alvi sought a fatwa from the Al-Azhar University of Egypt. The fatwa stood for social distancing, and it was mentioned that it is permissible to offer prayers in homes in times of diseases or any other problem (Hassan, 2020).

However, the clerics continued their congregational prayers in mosques. Mufti Taqi Usmani remarked, "It is not possible to get rid of this coronavirus without asking God for forgiveness." At the same time, Zameer Ahmad Naqvi claimed that he has a "special antidote" for the disease. Mufti Tariq Masood opposed those Islamic scholars who wanted to continue their congregational prayers. He supported the government on the issue of social distancing (Shah, 2020). The politicians, who always use religion for their political objectives, also responded to the pandemic in the same way. For example, Fayyaz-ul-Hasan Chohan, former information minister of the Punjab government, termed the coronavirus as a "punishment of God". The birth of a disabled child was linked to the "wrong deeds" of his parents (Ye Allah ka az'ab hai) (Inayat, 2020).

Conspiracy theories through social media spread very rapidly across the country. Such examples include statements like "the virus will not "infect" Muslims", and "It is a game to control the population of the world". It is a secret agenda of the Jews against the Muslims. Some people blamed the Shia community. Yet some others blamed the Tablighi Jamaat for spreading the pandemic in the country. According to the PM of the country, "COVID-19 is merely the flu," and people need not worry (Rafi, 2020). According to Maulana Tahir Ashrafi, the anti-Tablighi propaganda started from Israel (Message TV, 2020). His allegation was based on an article published in an Israeli newspaper. The article had mentioned that the Palestinian victims of the COVID-19 had come from Pakistan. However, it was confirmed by the 
Palestinian embassy in Islamabad that the two victims had participated in the Raiwind annual Ijtima. However, some others believed that it is a secret game of the Chinese government for world dominance, and it will not "affect" Pakistan because Pakistan has always been a good ally of the Chinese government (Amir, 2020).

A Barailve Islamic scholar requested his supporters to participate in an All-Pakistan Sunni Conference scheduled for March 21, 2020. He assured them that no one would be "affected" by a coronavirus. People replied by loudly saying the words of Subhan Allah, Subhan Allah' (South Asia Media Research Institute, 2020). A young Muslim who regularly attends the fivetime prayers said, "This is a curse from God, and we are turning towards the mosque because this is where our salvation lies." Another aged man said that this is a part of our faith that life and death are in the control of Allah. Mufti Masood Ahmad, who serves as a prayer leader in a mosque, said that even those who probably never visited the mosque before also started coming in. Perhaps, they saw this as a curse from God (Red Fish, 2020). Allama Zahir Akhtar, another religious scholar, claimed that he could control pandemics in Pakistan with the help of his religious knowledge.

Before the state could decide regarding the holy month of Ramzan, clerics belonging to different religious seminaries, political and non-political parties held a meeting at Jamia Darul Uloom Zakaria, Tarnol. They unanimously agreed to hold congregational prayers in the sacred month of Ramzan. Pir Azizur Rehman Hazarvi said, "the senior clerics have noted that all efforts will be made to avoid clash and confrontations with the government and state institutions" (Ali, 2020). The state could not resist the Islamists, and ultimately it opened places of worship for the Muslims in the holy month of Ramzan. Both the parties agreed on a 20-point standard operating procedure (SOPs). However, the most important question was how to implement these agreed SOPs? A survey shows that in the 194 union councils of Punjab, about 85 percent of the prayer-men did not follow the SOPs (Hayat, 2020).

The reaction and attitudes of the religious clergies reveal that they were not ready to accept the threat created by the coronavirus in the country. Holding religious festivals and public prayers in mosques seems to be very important and a matter of life and death for them. A time came when they accepted this threat. However, instead of closing their mosques, they tried to use religion and religious festivals as a coping strategy against the destructive effects of the coronavirus. They must have thought that the illness resulted because Allah the Almighty was not pleased with His servants. In order to make Him happy, the clergies rejected the recommended precautions of the state and continued their gatherings in the country. They considered the pandemic as an act of God, and only He could eradicate the illness forever.

\subsection{Resisting the $\mathbf{T J}$ and other Islamists}

Despite the open violation of these instructions, the Pakistani state remained a silent spectator. It could not take any action against religious leaders and faith-based organizations. The power of clerics lies in the street. It seems to be a valid reason due to which the state policymakers decided not to resist them. The use of the religious card for political objectives has played an essential role in state politics since its creation in August of 1947. The All-India Muslim League, a political party that struggled for Pakistan, also used religion in the freedom movement for Pakistan. The passing of the Objectives Resolution in March of 1949 set the stage for Islam in the political and administrative structure of the country. It mentions, "wherein the Muslims shall be enabled to order their lives in the individual and collective spheres in 
accordance with the teachings and requirements of Islam as set out in the Holy Qur'an and the Sunnah" (Khan, 2001, p. 57). The non-Muslim members of the constituent assembly put forward some proposed amendments, but the majority in the house rejected all their amendments. Therefore, it is apparent that the state leadership wanted for only Muslims to be enabled to live their lives according to the principles of their religion.

The country was disintegrated in the year 1971. One part of the country, called East Pakistan, got independence from the West Pakistan in December 1971. After this sad event, the political and military leadership of the state started relying more on Islam as opposed to taking any sort of good lessons from the regrettable decision to declare war. The state leadership thought that the Bengalis were not fully Islamized and that is why they "betrayed" West Pakistan in the war. Had they been good Muslims, they would have never "betrayed" the Islamic country. This idea came into the minds of the state managers after their defeat in the war. The state policymakers were not ready to accept the political, economic, and social factors that played a major role in the disintegration of Pakistan (Cohen, 2004). The new constitution of Pakistan made in 1973 incorporated more Islamic features. For example, Islam became the official religion of the state. They went a step further and defined a Muslim in clear words. The government of Zulfiqar Ali Bhutto (1971-1977) also used Islam as a tool for political objectives. Starting from military dictators to the so-called political leaders of the state, Islam has always been used to seize political powers. The current government of Imran Khan, formed in 2018, also promised to establish Riyast-i-Madina (the Islamic State of Madina at the time of Prophet Muhammad (Peace Be Upon Him) in Pakistan (Naqvi, 2020).

The TJ became very popular during the military rule of Zia-ul-Haq (1977-1988). Like the socalled political leaders of the state, the military dictator also used Islam to achieve political objectives. It was Zia who allowed the TJ to preach Islam in the military department of the state. He used to participate in the TJ Ijtima at Raiwind. Every possible help was given to the TJ during the military rule of Zia-ul-Haq. It is said that during this particular time, several military officers and soldiers became active Tablighis (Rizvi, 2003). During this particular time, the Pakistani military was converted into Allah's military. The Jamaat became very popular in the 1990s. According to Nadeem Paracha, the TJ had been the organization of the working and peasant classes until the 1980s. The change came in the 1990s when the TJ was joined by people from the upper and middle classes of the country (Paracha, 2011).

The TJ elders claim that the Jamaat has nothing to do with the politics of the country. They claim that TJ is a non-violent and apolitical movement in the world. According to Nizam (2008), one of the reasons due to which the TJ adopted an "apolitical" stance was that its founder believed that the Holy Prophet (PBUH) did not struggle to gain state power in Makkah and Madina. He worked on the people's hearts and strengthened their faith (iman) only (Nizam, 2008). However, some observers have questioned its apolitical slogan. Mayaram (2004) has argued that the ruling elite in the state has always welcomed the Tablighi Jamaat because the TJ is seen as a good source in maintaining the social order of the state (Mayaram, 2004). The political role of the TJ in Pakistan was observed when TJ decided to support the Mutahidda Majlis-i-Ammal (MMA), a political alliance of the Islamist parties in the general elections of 2002. This religious alliance of the Islamic political parties then formed government in the former NWFP (Khyber Pakhtunkhwa) (Zahid, 2015).

The relationship between the TJ and the state was established when the constituent assembly of Pakistan passed the Objectives Resolution in March of 1949. However, the relationship 
between the two was further strengthened when the 1973 constitution was passed. It was the 1973 constitution that declared Islam to be the official religion of the state, a religion for which the TJ had been struggling since its very foundation in the colonial period. Moreover, the TJ and the state are struggling to achieve one pious goal: transforming Pakistani Muslims into "good Muslims". In the preamble of the 1973 constitution, it is stated that, "Wherein the Muslims shall be enabled to order their lives in the individual and collective spheres under the teachings and requirements of Islam as set out in the Holy Quran and Sunnah" (The Constitution of Pakistan, 1973, p. 1). One can find a "sacred similarity" between the Tablighi Jamaat and the Pakistani state. This sacred alliance between the two enabled the TJ to hold its annual meetings amid the days of a dreadful disease. How could the state resist the TJ when the later work for a holy purpose for which the state has been struggling since the passing of the Objectives Resolution in March of 1949?

As far as other Islamists are concerned, the known history of Pakistan elucidates that the state has always followed the policy of appeasement towards them. In 2017 when the Tehrik-iLabbaik Pakistan (TLP) staged a violent protest against the state and challenged the security forces, the Pakistani military signed a "peace deal" with them. A military officer gave them envelopes full of cash for "travel expenses." The same organization led another violent protest against the Frech ambassador in early 2021. The state had to make several agreements with the banned organization (Dawn, 2021). Making one peace deal after another reveals the power, respect and popularity of the religious people in the country. It is argued that the state could not resist these religious people because it could create law and order problems in the country.

This study suggests that the response of TJ and other clerics belonging to other Islamic political parties or movements viewed the disease as an act of God. Holding such huge annual meetings by the TJ and the opposition of other religious leaders to close down places of worship should be understood in terms of religious coping. As we have written above, only religious people turn to God whenever they confront a life-threatening situation. The coronavirus pandemic constituted a severe threat to the county and its citizens. Therefore, the people of Pakistan firmly believed that the COVID-19 was a test of God. Knowing that the health system of the country was too weak, the people of Pakistan turned to God with the hope that He will keep them safe from the attack of COVID-19. This discussion supports the central argument of our paper that natural calamities increase religiosity in the people because people firmly believe that God is not happy with them. In order to make Him happy, people turned to God for support, spirituality and forgiveness.

\section{Conclusion}

There is no doubt that religion has always played a significant role in human societies across the globe. This role becomes very important when society faces a serious problem. During the time of the current pandemic, religious leaders did two things: They either accepted and cooperated with state authorities in the fight against the pandemic or rejected the virus as a conspiracy and continued their congregational prayers. Unfortunately, Pakistan experienced the second response of its clerics and other faith-based organizations. The Tablighi Jamaat did not cooperate with authorities when it was requested to postpone its annual meeting due to the possibility of the spread of coronavirus among its participants. In the second case, it was allowed by the state to hold its annual meeting. A state where Islam remains its official religion could not become a hindrance in the way of a religious organization working for the cause of spreading the official religion. The study has found that both the TJ and the state are pursuing 
one pious purpose. This study suggests that the elders of Tablighi Jamaat would have thought that the virus is an act of God and could be eliminated through spirituality.

The clerics of nearly every sect of Islam in the country considered the virus to be propaganda of the enemies of Islam. Some called it a Jewish conspiracy (yahodiyo'n ki sazesh) against Islam and Pakistan. Some clerics raised fingers on women's immodesty as the "real" reason behind the spread of coronavirus in Pakistan. Due to the availability of internet facilities and the use of social media networks in the country, the state and its intuitions failed to stop the spread of such propaganda. The state could not resist these Islamists from holding religious gatherings in the country. The ideology of faith politics plays a significant role in the state. Various examples in the country shows that taking actions against the clergies has always earned a bad name for the state and its managers. This study has suggested that the response of the $\mathrm{TJ}$ and other clerics is the best example of a religious coping strategy. Already religious in their lives, they tried to get closer to Allah Almighty. This study argues that the current pandemic increased religiosity across Pakistan. The role of religion and religious organizations amid the current pandemic in Pakistan is a welcoming area for further research.

\section{Declaration of conflict of interest}

The author(s) declared no potential conflicts of interest(s) with respect to the research, authorship, and/or publication of this article.

\section{Funding}

The author(s) received no financial support for the research, authorship and/or publication of this article.

\section{References}

Agha, A. (2020, July 7). Is Tablighi Jamaat a variant of Islam? http://dspace.jgu.edu.in:8080/jspui/bitstream/10739/3588/1/Is\%20Tablighi\%20Jama at $\% 20 \mathrm{~A} \% 20$ Variant $\% 200 \mathrm{O} \% 20$ Islam\%3F.pdf

Ahmad, R. (2020, March 30). Tablighi Jamaat members continue to defy lock-downs. Samaa $T V . \quad$ https://www.samaa.tv/news/pakistan/2020/03/tablighi-jamaat-memberscontinue-to-defy-lockdowns/

Ahmed, I. (2020). The politics of congregational prayer: Trust, public health, and religious authority in Pakistan. Journal of Law, Religion and State, 8(2-3), 251-271. Doi: https://doi.org/10.1163/22124810-2020015

Alami Shura. (2020, November 10). Maulana Ibrahim dewla bayan. YouTube. https://www.youtube.com/watch?v=Y28Xi0_SNIY\&t=3131s\&ab_channel=AalmiS hura

Al-Falah official. (2020, May 4). The message of Tablighi Jamaat. YouTube. https://www.youtube.com/watch?v=gpH2DKUrJho\&ab_channel=AlFalahOfficial

Ali, K. (2020, April 14). Clerics warn govt not to extend prayers restrictions during Ramazan. Dawn. https://www.dawn.com/news/1548978

Amir, A. (2020, June 13). Conspiracy theories help coronavirus take root in Pakistan. Nikkei 
Asiar. $\quad$ https://asia.nikkei.com/Spotlight/Coronavirus/Conspiracy-theories-helpcoronavirus-take-root-in-Pakistan

Ano, G. G., \& Vasconcelles, E. B. (2005). Religious coping and psychological adjustment to stress: A meta-analysis. Journal of clinical psychology,61(4), 461-480. https://doi.org/10.1002/jclp.20049

Badshah, S. L., \& Ullah, A. (2020). Spread of Coronavirus disease-19 among devotees during religious congregations. Annals of Thoracic Medicine, 15(3), 105. https://www.ncbi.nlm.nih.gov/pmc/articles/PMC7423201/

Being Ummat. (2020, November 7). Raiwind Ijtima 2020: Maulana Farooq Benglore bayan. YouTube. https://www.youtube.com/watch?v=ev2_2IU8MTM\&ab_channel=BeingUMMAT

Being Ummat. (2020, November 6). Raiwind Ijtima: Maulana Umar Ahmad Bayan. YouTube. https://www.youtube.com/watch?v=KNRPuj9Rg5A\&ab_channel=BeingUMMAT

Bentzen, J. (2020). In crisis, we pray: Religiosity and the COVID-19 pandemic. CEPR Discussion Paper. https://ssrn.com/abstract $=3615587$

Butt, Q. (2020, October 16). Limited Tablighi Ijtima with SOPs on November 5. The Express Tribune. https://tribune.com.pk/story/2268576/limited-tablighi-ijtima-with-sops-on$\underline{\text { nov-5 }}$

Chaudhery, A. (2020, April 8). Tablighi Jamaat in hot water in Pakistan too. Dawn. https://www.dawn.com/news/1547354

Chen, D. L. (2008). Club Goods and Group Identity: Evidence from Islamic Resurgence During the Indonesian Financial Crisis. Journal of Political Economy, 118(2), 300-354. https://www.journals.uchicago.edu/doi/abs/10.1086/652462

Clark, A., \& Lelkes, O. (2005). Deliver Us from Evil: Religion as Insurance. https://www.researchgate.net/publication/5081440_Deliver_Us_From_Evil_Religio $\mathrm{n}$ as_Insurance

Cohen, S.P. (2004). The idea of Pakistan. Brookings Institution Press.

Dawn. (2020, November 3). Raiwind Congregation Allowed with Set of Guide. https://www.dawn.com/news/1588346

Dawn. (2021, April 14). TLP Protests. https://www.dawn.com/news/1618136

Evan, E. (2020, June 13). Here is what the science says about the links between religion and health. The Desert News. https://www.deseret.com/indepth/2020/6/13/21273906/coronavirus-faith-religionhealth- science-link-prayer-study-longevity-covid-19-substance-use

Frei-Landau, R. (2020). When the going gets tough, the tough get-creative: Israeli Jewish religious leaders find religiously innovative ways to preserve community members' sense of belonging and resilience during the COVID-19 pandemic. Psychological Trauma: Theory, Research, Practice, and Policy, 12(1), 258-260.

Government of Pakistan. (2020, December 12). Pakistan cases details. https://covid.gov.pk: https://covid.gov.pk/stats/pakistan

Hadid, D. (2020, March 23). Mass religious gathering in pakistan leads to fresh concerns over COVID-19 spread. NPR. https://www.npr.org/sections/coronavirus-liveupdates/2020/03/23/820043866/mass-religious-gathering-in-pakistan-leads-to-freshconcerns-over-covid-19-sprea

Hashmi, F. K., Iqbal, Q., Haque, N., \& Saleem, F. (2020). Religious cliché and stigma: A brief response to overlooked barriers in COVID-19 management. Journal of religion and health, 59(6), 2697-2700. https://doi.org/10.1007/s10943-020-01063-y

Hassan, Y. (2020, April 21). COVID-19 \& religious fanaticism in Pakistan. Manohar Parrikar 
Institute for Defense Studies and Analyses. https://idsa.in/idsacomments/covid-19religious-pakistan-yuhassan-210420

Hayat, K. (2020, April 30). Duel till death. The News. https://www.thenews.com.pk/print/651647-duel-till-death

Hill, T. D., Kelsey. G., \& Burdette, A. M. (2020). The blood of christ compels them. The Journal of Religion and Health, 59(5), 2230-2231. https://doi.org/10.1007/s10943020-01058-9

Hollinger, F., \& Muckenhuber, J. (2019). Religiousness and existential insecurity: A crossnational comparative analysis on the macro-and micro-level. International Sociology, 34(1), 19-37. https://doi.org/10.1177/0268580918812284

Immerzeel, T., \& Tubergen, F. V. (2020). Religion as reassurance? Testing the insecurity theory in 26 European countries. European Sociological Review, 29(2), 359-372. https://doi.org/10.1093/esr/jcr072

Inayat, N. (2020, April 30). Pakistani cleric close to Imran Khan has found what caused the corona pandemic. The Print. https://theprint.in/opinion/letter-frompakistan/pakistani-cleric-close-to-imran-khan-has-found-what-caused-coronaviruspandemic/411

Inayat, N. (2020, March 19). Why Pakistan is the most chilled out in a world hit by Coronavirus. The Print. https://theprint.in/opinion/letter-from-pakistan/whypakistan-is-the-most-chilled-out-in-a-world-hit-by-coronavirus/383458/

Iqra Media House. (2020, November 8). Raiwind Alami Ijtima 2020: Maulana Ahmad Laat Sahib Bayan. YouTube. https://www.youtube.com/watch?v=WCkSb1CFaPI\&t=1021s\&ab_channel=IqraMe $\underline{\text { dia }}$

Jawed, H. (2020). Pandemic Coronavirus COVID-19 spread in Pakistan in 2020. Journal of Respiratory Research, 6(1), 148-151. http //www.ghrnet.org/index.php/jrr/article/view/2950

Kermani, S. (2020, March 20). Coronavirus: Nowruz festival overshadowed by Outbreak. $B B C$. https://www.bbc.com/news/world-asia-51966125

Khan, H. (2001). Constitutional and political history of Pakistan. Oxford University.

Krause, N. (2009). Religious involvement, gratitude, and change in depressive symptoms over time. The International Journal for the Psychology of Religion, 19(3), 155-172. Doi: 10.1080/10508610902880204

Mahmood, A. (2020, March 27). Mufti Taqi Usmani gives Fatwa about Jumma prayers amid coronavirus crisis. Business Recorder. https://www.brecorder.com/news/584043

Mamun, S. (2019). Tablighi Jamaat: An Islamic revivalist movement and radicalism issues. Islam Realitas: Journal of Islamic and Social Studies, 5(2), 145-159.

Mayaram, S. (2004). Hindu and Islamic transnational religious movements. Economic and Political Weekly, 39(1), 80-88. https://www.jstor.org/stable/4414467

Message TV. (2020, April 2). How and when campaign started against Tablighi Jamaat. YouTube.

https://www.youtube.com/watch?v=ANeHbxj4NzM\&t=273s\&ab_channel=Messag eTvofficial

Nadwi, A. H. A., \& Kidwai, M. A. (1979). Life and mission of Maulana Mohammad Ilyas. Academy of Islamic Research and Publications.

Naqvi, S. (2020, April 23). The surrender before clergy: There was no other way for Imran Khan. Naya Daur. https://nayadaur.tv/2020/04/the-surrender-before-clergy-therewas-no-other-way-for-imran-khan/ 
National Assembly of Pakistan. (1973). The constitution of the Islamic Republic of Pakistan.

Nizam, I. (2008). Development of Islamic movements in modern India. Unpublished Ph.D. Thesis, Aligarh Muslim University.

Noreen, N., Dil, S., Niazi, S., Naveed, I., Khan, N., Khan, F., \& Kumar, D. (2020). COVID 19 pandemic \& Pakistan; Limitations and gaps. Global Biosecurity, 1(4). DOI: http://doi.org/10.31646/gbio.63

Norris, P., \& Inglehart, R. (2011). Sacred and secular: Religion and politics worldwide. Cambridge University.

Paracha, N. (2020, May 10). God's wrath or natural science? Dawn. https://www.dawn.com/news/1555860

Paracha, N. (2011, April 21). Like army, like nation. Dawn. https://www.dawn.com/news/622658/like-army-like-nation

Pargament, K. I., Ensing, D. S., Falgout, K., Olsen, H., Reilly, B., Van Haitsma, K., \& Warren, R. (1990). God help me:(I): Religious coping efforts as predictors of the outcomes to significant negative life events. American journal of community psychology, 18(6), 793-824. https://link.springer.com/article/10.1007\%2FBF00938065

Pirutinsky, S., Cherniak, A. D., \& Rosmarin, D. H. (2020). COVID-19, mental health, and religious coping among American Orthodox Jews. Journal of Religion and Health, 59(5), 2288-2301. https://link.springer.com/article/10.1007/s10943-020$\underline{01070-\mathrm{Z}}$

Quadri, S. A. (2020). COVID-19 and Religious Congregations: Implications for Spread of Novel Pathogens. International Journal of Infectious Diseases, 96, 219-221. https://www.ijidonline.com/article/S1201-9712(20)30313-1/fulltext

Rafi, M. S. (2020). Dialogic Content Analysis of Misinformation about COVID-19 on Social Media in Pakistan. Linguistics and Literature Review, 6(2), 136-137.

Raza, I. (2020, April 21). Ulama back PM's stance on lockdown. Dawn. https://www.dawn.com/news/1550972

Red Fish. (2020, May 8). Faith and fear: Pakistan's COVID-19 response. YouTube. https://www.youtube.com/watch?v=wkBTE838z8c\&ab_channel=redfish

Rizvi, H. (2003). Military, State, and Society in Pakistan. Sang-i-Meel Publications.

Sahu, I. (2020, March 11). Raiwind Tablighi Ijtima in March 2020. Youtube. https://www.youtube.com/watch?v=y6CKGe_i38E\&ab_channel=Idrees

Sahu, I. (2020, March 12). Raiwind Tablighi Jor in March. YouTube. https://www.youtube.com/watch?v=mrAOixkIJyQ\&ab_channel=Idrees

Samaa TV. (2020, March 18). Maulana Tariq Jamil exclusive. YouTube. https://www.youtube.com/watch?v=H2qzdoQjCVw\&ab_channel=SAMAATV

Sattar, N. (2020, April 3). Muslims response. Dawn. https://www.dawn.com/news/1546045

Shah, H. A. (2020, March 26). Pakistani clerics divided despite Al-Azhar Fatwa to suspend congregational prayer. The News. https://www.thenews.com.pk/latest/634873coronavirus-pakistani-clerics-divided-despite-al-azhars-fatwa-to-suspendcongregational-prayers

Shahid, K. K. (2020, April 1). Islamists are frustrating Pakistan's fight against coronaviruses. The Spectator. https://www.spectator.co.uk/article/islamists-are-frustratingPakistan-s-fight-with-coronavirus

Siddiqi, B. (2010). Purification of self': Ijtema as a new Islamic Pilgrimage. European Journal of Economic and Political Studies, 133-150.

South Asia Media Research Institute. (2020, March 16). https://twitter.com/SAMRIReports/status/1239336926471172108 
Sulkowski, L., \& Ignatowski, G. (2020). Impact of COVID-19 pandemic on organization of religious behaviour in different Christian denomination in Poland. Religions, 11(5), 254. https://doi.org/10.3390/rel11050254

Suyadi., Nuryana, Z., \& Fauzi, N. A. F. (2020). The fiqh of disaster: The mitigation of COVID19 in the perspective of Islamic Education-neuroscience. International Journal of Disaster Risk Reduction, 51, 101848. https://doi.org/10.1016/j.ijdrr.2020.101848

Tablighi Bayanat Official. (2020, December 23). YouTube. https://www.youtube.com/watch?v=fg6vLWMFYvc\&ab_channel=TablighiBayanaa $\underline{\text { tOfficial }}$

The International Crisis Group. (2020, August 6). Pakistan's COVID-19 crisis. https://www.crisisgroup.org/asia/south-asia/pakistan/b162-pakistans-covid-19-crisis

TRT World. (2020, March 31). Pakistan's COVID-19 challenge. YouTube. https://www.youtube.com/watch?v=cTrRf4v6AG4\&ab_channel=TRTWorld

World Health Organization. (2020). COVID 19 public health emergency of international concern. https://www.who.int/publications/i/item/responding-to-community-spreadof-covid-19

World Health Organization. (2020, April 7). Practical considerations and recommendations for religious leaders and faith-based communities in the context of COVID-19. https://www.who.int/publications/i/item/practical-considerations-andrecommendations-for-religious-leaders-and-faith-based-communities-in-thecontext-of-covid-19?gclid=CjwKCAjw55-

HBhAHEiwARMCsznwd4_oqTMNskX0iSwfIuwvZbatEDirxzlkikqLDitArTg89rG iRJhoCGNAQAvD BwE

Yulianto, H. I. (2020, June 17). How religions and religious leaders can help to combat the COVID-19 Pandemic: Indonesia's experience. The Conversation. https://theconversation.com/how-religions-and-religious-leaders-can-help-tocombat-the-covid-19-pandemic-indonesias-experience-140342

Zahid, F. (2015). Tablighi Jamaat and Its links with Islamic terrorism. https://cf2r.org: https://cf2r.org/foreign/tablighi-jamaat-and-its-links-with-islamist-terrorism-2/

Zi, Yue, J., Ming, C., Wen, N., Qian, L., Guang, \& Z, Long. (2020). Coronavirus disease 2019 (COVID-19): A perspective. Radiology, 296(2), 15-25. https://doi.org/10.1148/radiol.2020200490 